\title{
O Sistema Político Brasileiro hoje: o governo do Supremo Tribunal Federal e legitimidade democrática
}

\section{Resumo}

Numa perspectiva tradicional, cujo quadro teórico é a teoria da separação de poderes, de formulação europeia continental, os órgãos do Poder Judiciário não são vistos como elementos genuínos do sistema governamental. Este artigo tem com objetivo central propor e desenvolver a tese de que o Supremo Tribunal Federal é um elemento original do governo brasileiro. Adotou-se como contraponto crítico a ideia bem difundida de que qualquer ato de governo do Supremo Tribunal Federal implica uma usurpação na forma de uma assim chamada judicialização da política. Buscou-se evidenciar, contra crenças ainda não de todo modificadas, a atuação precípua e funcional do Supremo na produção do discurso político, bem como identificar a forma como os ministros do Supremo Tribunal Federal se posicionam em relação ao fato de atuarem na produção da ordem política. Buscou-se, ainda, através da análise do conteúdo dos votos proferidos pelos ministros, registrar a presença de palavras ou expressões que configurassem, dentro do discurso principal, metadiscursos, que dessem alguma pista acerca da autoimagem e legitimidade correlata.

Palavras-chaves: Supremo Tribunal Federal. Função política originária. Legitimidade democrática. Ministros. Metadiscurso.

\footnotetext{
" Doutorando em Sociologia pelo Programa de Pós-graduação do Instituto Universitário de Pesquisa do Rio de Janeiro da Universidade Cândido Mendes. Procurador da República pelo Ministério Público Federal no estado do Rio de Janeiro. (Brasil) E-mail: eduardobenones@gmail.com
} 


\title{
The Brazilian political system nowadays: the rule of the Su- preme Court and the democratic legitimacy
}

\begin{abstract}
From a traditional perspective whose theoretical framework is the so-called theory of separation of powers formulated in continental Europe, the organs of the judiciary are not seen as genuine elements of the governmental system. This article proposes and develops the central thesis that the Federal Supreme Court is an original element of the Brazilian government. The widespread idea that any act of government by the Supreme Court involves a misappropriation in the form of a so-called judicialization of politics was adopted as a critical counterpoint. Against beliefs that remain rather unchanged, we tried, on the one hand, to demonstrate the relevant and functional role of the Supreme Court in the production of a political discourse. On the other hand, we sought to identify how the ministers of the Supreme Court see the fact that they act in the production of the political order. In addition, by means of content analysis of judgments issued by ministers, we sought to detect the presence of words or expressions that might represent metadiscourses within the main discourse, and which could give some clue about their self-image and correlated legitimacy.
\end{abstract}

Keywords: Federal Supreme Court. Original Political Function. Democratic legitimacy. Ministers. Metadiscourse.

\section{Introdução}

Max Weber sosteneva che per attuare una politica responsabile era necessario possedere una conoscenza valida delle relazione empiriche tra i fenomeni della vita sociale. Richiamandosi all"insegnamento di Macchiavelli, Weber giungeva alla conclusione che l'analise della politica deve prendere le distanze dalla politica come si

svolge nella pratica. Il compito dello studioso consiste nel separare "ciò che è" da "chio que dovrebbe essere"

(Giorgio Sola) 


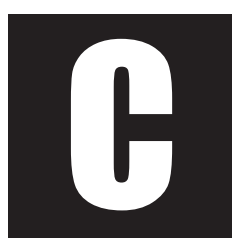

om a Promulgação da Constituição de 1988, o Brasil consolida a abertura política iniciada em 1975, sob o governo do General Ernesto Geisel. Os eventos políticos ocorridos nesse período da história brasileira podem ser reconduzidos ao amplo quadro de abertura democrática verificado na América Latina. Este movimento ficou conhecido como a "terceira onda", nome com o qual o escritor americano Samuel P. Huntington trata, em chave politológica, a queda das ditaduras de Portugal, Espanha e dos países da América Latina (Huntington, 1995).

No caso brasileiro, a redemocratização implicou na queda do Regime Militar ${ }^{1}$ passando pela eleição indireta de um presidente civil e culminando na redação de um texto constitucional extenso. Este voltado, a um só tempo, à consagração das liberdades e garantias individuais, e à abolição de resquícios institucionais do Regime Militar. Tudo isso, sem prejuízo do fato de que a Constituição atendeu aos mais variados interesses.

Neste diapasão, pode-se afirmar que, no Brasil contemporâneo, há um sistema político o qual se subsume à classificação de um sistema político-democrático. Assumindo este pressuposto, sem entrar na discussão entre substancialistas e formalistas, e considerando que o militarismo é uma lembrança bem viva no imaginário nacional, uma questão pode ser formulada: o quanto é democrático o Sistema Político Brasileiro?² Formulando em termos mais claros o problema: qual é o grau de autonomia do cidadão na sua relação com o governo brasileiro? Ou ainda: qual é o grau de participação popular naqueles processos decisórios que resultam em diminuição da autonomia individual?

\footnotetext{
${ }^{1}$ A propósito deste período, foi criada e instalada a Comissão Nacional da Verdade, no âmbito do executivo, e os grupos de trabalho denominados 'justiça de transição', no âmbito do Ministério Público Federal.

${ }^{2} \mathrm{~A}$ formulação é tomada de empréstimo a Robert Dahl, in: o quanto è democrática la costituzione America?
} 
Antes de tudo, é necessário aclarar um conceito. Muito se fala em sistema político. Mas o que exatamente significa o termo 'sistema políti$\mathrm{Co}^{\prime}$ ? Simplistamente, um sistema pode ser descrito como um conjunto no qual os vários elementos interagem unificados por um princípio comum. O termo político, por seu turno, refere-se ao fato de que existem decisões que vinculam de um modo, mais ou menos extenso, toda a coletividade. É possível afirmar, então, que um sistema político qualquer é uma subespécie de sistema social (Luhmann, 1998), dentro do qual os vários elementos estão voltados à produção de discursos impostos, coercitivamente, a uma determinada coletividade.

Para retomar a questão de saber se o Sistema Político Brasileiro é mais ou menos democrático, faz-se imperioso lançar um olhar categorizado para nossa realidade política e indagar: quais são, na perspectiva institucional, os elementos orgânicos deste sistema? Aqui, a pedra fundamental de toda a nossa argumentação. A comunidade jurídico-constitucional brasileira aceita, de longa data, o assim chamado princípio da separação de poderes, conferindo-lhe, inclusive, sítio específico na Constituição da República. Por tal doutrina de justificação ${ }^{3}$, cuja formulação teórica remonta a Montesquieu, os juízes e os Tribunais não são encarados como titulares e operadores genuínos de poder político. Ou seja, os juízes e os respectivos tribunais não tomam, ou não deveriam tomar decisões coletivamente vinculantes, ou genéricas, na medida em que se crê que o papel dos que exercem o Poder Judiciário é a resolução de casos concretos, por meio de fórmulas pré-estabelecidas, ou construídas, consensualmente, no espaço forense. Em suma, um agente do Poder Judiciário não é um agente político.

\footnotetext{
${ }^{3}$ Usamos esta expressão 'doutrina de justificação' numa alusão à 'fórmula política' como termo e conceito elaborado por Gaetano Mosca. Como ainda se discutirá neste artigo, a expressão 'separação de poderes' mais justifica do que explica, e não implica em 'poderes separados' de fato.
} 
De acordo com esta visão, o Sistema Político Brasileiro é distinto de seu Sistema Jurídico. O primeiro seria composto, de um ponto de vista orgânico, pelo Congresso Nacional e pela Presidência da República; o segundo, por todos os juízes e tribunais do país, encimados por um órgão jurisdicional de cúpula, denominado pela Constituição de Supremo Tribunal Federal (STF).

Todavia, apesar de distintos na geografia constitucional, é íntima a relação entre ambos, uma vez que o Brasil se insere na tradição da civil law. Daí, poder se afirmar que existe um sistema político construtor do sistema jurídico, ou, em outras palavras, que o discurso político opera como uma gramática, balizando a construção do discurso jurídico. E, neste contexto, haveria o primado do Poder Legislativo sobre o Poder Judiciário.

A exata compreensão da realidade política brasileira requer do observador, segundo se acredita, uma postura epistemológica sistêmica. O que implica empregar nas reflexões e pesquisas acerca do fenômeno político, mais do que meramente a palavra sistema ${ }^{4}$, os conceitos próprios às teorias de corte sistêmico. A abordagem causalista, herdada da física clássica, com suas análises e decomposições atomísticas pode produzir um tipo de conhecimento parcial e enganoso, pois hierarquiza elementos que, em verdade, estão em constante interação. O método analítico, porque baseado na crença de que todo efeito tem uma e única causa, tende a isolar duas variáveis a fim de dar conta de dado fenômeno. Com isso, despreza-se o caráter multifacetário da realidade, mormente da realidade social contemporânea, de cuja complexidade já ninguém duvida.

\footnotetext{
${ }^{4}$ Observa-se que a palavra sistema é de uso corrente tanto na linguagem leiga quanto especializada, sobretudo nos léxicos jurídico e político. Deste modo, fala-se, v.g., em sistema tributário, sistema prisional, sistema de justiça. Alude-se às mazelas do sistema, às falhas do sistema de governo, dentre outros usos cotidianos da palavra. O que parece relevante é que a palavra sistema foi incorporada aos ditos léxicos, mas há mostras de que o conceito de sistema, o modo sistémico de abordar o real não o tenha sido, ou não o tenha sido em todos os casos.
} 
Só mesmo uma postura mecanicista poderia ter produzido a crença de que a atuação política do STF decorra do que chamaram judicialização da política. O termo judicialização, embora usado na descrição de um fenômeno, refere, no fundo, uma teoria ou uma hipótese. Ao perceberem o Supremo governando (este é o fenômeno), os observadores concluíram que ele estava fazendo algo que não deveria fazer. Afinal, numa visão atomista, o STF é um tribunal, e tribunais, mormente em países da civil law, não governam. Com isso, a atuação política do STF, quando percebida, o é como um desvalor e como uma disfuncionalidade, dado o caráter supostamente usurpador da dita atuação.

Mas, assumindo um modelo sistêmico da realidade política brasileira é possível, sem espanto, compreender a atuação do Supremo. Primeiramente, retomando, entremos em acordo sobre o que queremos dizer quando falamos de um sistema político. Um sistema qualquer é um conjunto de elementos em interação (Bertalanfy, 1989). Com base nesta definição, pode-se buscar descrever um sistema político como um conjunto interagente de instituições unificadas pela produção de decisões coletivamente vinculantes. Obviamente, uma decisão que vincule toda uma coletividade há de estar baseada em escolhas mediadas pela vontade dos que decidem, ou seja, não podem estar previstas letra por letra num código jurídico anterior.

Desse modo, o que há de comum entre o STF, o Congresso Nacional e a Presidência da República é o discurso. Estas instituições produzem um tipo de discurso que, para citar David Easton (Easton, 1963), além de alocarem imperativamente valores sociais, operam como uma gramática na produção de outros discursos de poder. Entanto, o que confunde é que estes discursos vinculantes (elemento comum às três instituições), por serem a ponta de um iceberg, acabam por não receber um tratamento unificado nem na teoria, nem na prática. Isso ocorre, retomando o tema, exatamente porque o intér- 
prete tanto quanto o crítico das decisões políticas do Supremo adotam uma postura mecanicista na tentativa de explicar o fenômeno político ao qual denominam judicialização da política. Por isso, e à moda positivista, saem à procura de uma causa ou, quando muito, entrelaçam apenas duas variáveis (o que na prática dá no mesmo). O STF, costuma-se dizer, está produzindo de fato um discurso político, porque (causa-efeito) está ocupando um espaço deixado pelo verdadeiro legislador (o Congresso).

Temos, então, duas visões, ambas de corte epistemológico positivista e mecanicista. Para a primeira, sequer há um sistema e cada elemento ou instituição é considerado isoladamente. Trata-se de uma leitura forte da doutrina da separação de poderes. É uma visão normativa e que, já por isto, não considera as coisas como elas são, mas como seria melhor que fossem, segundo uma dada crença ou modelo. No caso, a crença é a de que à separação de poderes e de nomes adotada no texto da Constituição da República corresponda uma separação real. Desta leitura forte da separação de poderes, a qual não encontra sequer um suporte histórico, decorre algo como uma resistência, em linha de princípio, à atividade legislativa de um órgão, o STF, que formalmente integra ou é investido de Poder Judiciário. Para a segunda visão, o Sistema Político existe enquanto tal, ou, pelo menos, assim é chamado. A leitura da doutrina da separação de poderes é aqui atenuada, embora apenas nominalmente. Reconhece-se que os Poderes Legislativo, Executivo e Judiciário são exercidos, em certa medida, por todos os órgãos, mas a postura epistemológica não muda. Os elementos (as instituições) são apenas justapostos. Percebe-se uma aproximação, mas não uma interação. Daí, mais uma vez perde-se a capacidade explicativa, na medida em que os isomorfismos não são reconduzidos a um quadro único, no qual o todo seja explicado não pela soma das partes, mas pela interação entre elas. 
Registre-se que o predito "princípio da separação de poderes", conquanto possa ter uma matriz filosófica, pode ser tomado evolutivamente, como uma forte representação social com bases doutrinárias e acadêmicas. Com efeito, o livro 'De L'esprit des lois' foi publicado no contexto político de uma França absolutista, contra o pano de fundo de uma Inglaterra parlamentarista. Montesquieu tinha os "olhos" postos em dois sistemas diversos quanto à titularidade do poder político. Ainda que sua descrição não obedeça a padrões e métodos científicos, não deixa de ser o relato de um observador da cena. A propósito, o cientista social Raymond Aaron (2003) postula, para Montesquieu, um lugar no panteão da sociologia, no mínimo, na condição de precursor.

Poderes separados, em acordo com a doutrina de Montesquieu, passam a ser algo desejável e, mais do que isto, um discurso esteticamente agradável e apaziguador de tensões e contradições ínsitas aos sistemas políticos contemporâneos. É neste prisma que a Constituição de 1988 preconiza, de plano, que os poderes são separados e harmônicos. O problema com a doutrina da separação de poderes, posta nestes termos, não é exatamente sua verificabilidade. Acredita-se, pelas razões a serem expostas, que a 'separação de poderes' possui, sim, valor de hipótese científica, e é, pois, testável. A questão é: na medida em que não é assumida como hipótese, não é posta, metodologicamente, à prova. A separação de poderes, seja alcunhada de princípio, de premissa lógica, de teoria ou de doutrina, assume um núcleo dogmático desdenhando-se-lhe o plano normativo. 'Os poderes são separados e harmônicos' é uma estrutura frasal de viés descritivo que assume o lugar de: 'os poderes deviam ser separados e harmônicos'.

Do ponto de vista da experiência, o que contribui para essa inversão é um fato tão singelo quanto pouco observado. O programa das faculdades de direito, primeiro lócus do que podemos chamar socialização jurídica, ensina a dita separação de poderes como enunciado descritivo. A comuni- 
cação dos saberes constitucionais, ao menos no nível massivo da graduação jurídica, passa-se, de modo geral, acriticamente, para não dizer ingenuamente. Comunica-se que os poderes são netamente separados e, ainda por cima, e contraditoriamente, harmônicos. Cada órgão (instituição) realiza uma função preestabelecida. Num aparente truísmo, diz-se que o judiciário julga, o legislativo legisla e executivo executa (!). E, nesse ponto, talvez premidos pela realidade teimosa em insinuar-se entre o profissional do foro e o lócus acadêmico, concede-se, vez por outra, que a relação entre órgãos e funções é indesejavelmente assimétrica por malferir uma espécie de ordem, a qual, no fundo, não passa de pureza conceitual.

Pretende-se, com isso, afirmar que a interface entre professores/ alunos e alunos/alunos na experiência total das relações acadêmicas em salas de aula ou em outros ambientes (o foro, por exemplo, durante estágios) contribui para a formação e solidificação de representações sociais. Utiliza-se o termo representação social, neste texto, numa alusão proposital à teoria das representações sociais, tal como elaborada e discutida por Serge Moscovici (2011). Na raiz do pensamento de Moscovici, está a origem social do conhecimento e, assim, suas bases compartilhadas. Vemos o mundo e interagimos uns com os outros por meio de representações. O lado imagético dessas representações é a realidade para nós. Os olhos são substituídos por categorias. Tanto assim que, comunidades, tais como a comunidade jurídica, são definidas epistemologicamente pelo conhecimento, pelas representações e crenças compartilhadas e com as quais interagem. Nesse sentido, pode-se afirmar que a separação de poderes, para além de uma premissa filosófica, embora também o seja, é uma categoria compartilhada do pensamento jurídico. Como tal, ela forja tanto uma realidade (poderes separados) quanto um estranhamento (o Tribunal fazendo política). A não assunção da separação de poderes como variável pode implicar numa barreira epistemológica, no que tange à compreen- 
são de como se dá a relação entre os diversos órgãos que compõem o sistema político-constitucional brasileiro ${ }^{5}$.

Feitas essas considerações, estamos em condições de expor ao leitor a premissa fundamental, sobre a qual procuramos contribuir com uma nova abordagem do Sistema Político Brasileiro. O STF é, nos termos da Constituição Brasileira, e tendo em vista a sua atuação real, um elemento orgânico de nosso sistema político. De acordo com essa perspectiva, o STF opera funcionalmente como órgão de governo, conectado à Presidência da República e ao Congresso Nacional.

Portanto, considera-se o Supremo como integrante do sistema político, participando ativamente da construção da ordem política. Ou seja, hoje, no Brasil, o discurso político é orgânica e precipuamente construído, também, pelo e no STF.

Nesse contexto, considerando o objetivo do presente trabalho, importa expor que, conceitualmente, um sistema de governo qualquer é tanto mais democrático quanto mais o povo participe de, pelo menos, um dos seguintes eventos: (i) o processo de tomada de decisões coletivamente vinculantes; ou (ii) o processo de escolha daqueles - entre o povo - que tomarão decisões coletivamente vinculantes.

Ora, se não há participação popular alguma em nenhum desses dois processos, então, ao menos de um ponto de vista teórico, não se está falando de democracia.

\footnotetext{
${ }^{5}$ Faz-se referência a um sistema político brasileiro e utiliza-se não somente da palavra, mas do conceito de sistema como encontrado na literatura pertinente. Pensa-se, especialmente, em Niklas Luhmann (Luhmann, 1990) com suas definições de sistema/ambiente e de redução sistêmica de complexidade. Na literatura jurídica brasileira, como se discute neste trabalho, a magistratura e os próprios tribunais não são alocados no sistema político. Como a presente pesquisa e reflexões apontam para uma direção diferente, sempre que se fala em sistema político, tem-se em mente um feixe de relações interdependentes das quais fazem parte os juízes e Tribunais Superiores, tanto quanto as casas legislativas e os órgãos do Poder Executivo. Visto assim, saber o que é sistêmico e que é ambiental no jogo de poder torna-se de crucial importância.
} 
Por outro lado, a participação do maior número possível de habitantes de um Estado (país) em pelo menos um dos dois processos sobreditos, configurará um sistema mais ou menos democrático. Daí se poder afirmar que a democracia é um predicado e, nessa ordem de ideias, uma variável dependente da participação popular em um dado sistema político.

Nesse caso, a maior ou menor participação popular na tomada de decisões pode ser tomada como variável independente e sintetizada na fórmula: "legitimidade governamental". Ora, o nosso problema aqui, então, é saber ou indagar o grau de legitimidade governamental das decisões do STF. O entrelaçamento das variáveis aqui propostas nos permite supor que o sistema político governamental brasileiro é menos democrático do que faz crer o seu discurso constitucional. Isso ocorre na exata medida em que falece, nos termos da categorização aqui proposta, legitimidade ao conjunto das decisões do STF ${ }^{6}$.

A fim de demonstrar essa hipótese, primeiramente, nos valemos de uma investigação visando a expor como a agenda do STF é formada. Com isso, pretendíamos averiguar o grau de participação popular nas questões propostas ao STF. Em seguida, investigar como os próprios ministros lidam com o fato de serem, formalmente, membros do Poder Judiciário, e, materialmente, atualizarem uma agenda governamental com repercussão, como já referido, na vida da nação.

O exame realizado demonstrou que as questões submetidas ao STF, não importando sua roupagem, afetam a vida nacional, às vezes nos seus mais comezinhos aspectos. As soluções de tais questões podem perfeitamente ser enquadradas na categoria "decisão política", na qual ingressam as decisões que, embora não emanadas, efetivamente, dos homens

\footnotetext{
${ }^{6}$ Para os efeitos deste artigo, não se põe a questão de saber se, em sendo assim, o sistema torna-se melhor ou pior. Anima-nos o propósito de contribuir na produção de um conhecimento que possa, antes de mais nada, desvelar a realidade institucional.
} 
e mulheres de uma dada comunidade, vinculam tais pessoas a ponto de poderem ser impostas coercitivamente.

Se a abordagem até aqui realizada estiver correta, isto é, em sendo o STF uma instituição originariamente política e funcionalmente um elemento precípuo do nosso sistema de governo, então é lícito afirmar que está aplainado o terreno sobre o qual construiremos a argumentação para responder nossa questão principal: quão democrático é o Sistema

\section{Político Brasileiro?}

\section{O Supremo e sua legitimidade democrática}

O STF foi criado em 1891 e, desde então, é tido como órgão de cúpula do Poder Judiciário. Em 1988, foram ampliadas suas atribuições, não só em razão do aumento do rol de legitimados à propositura de Ação Direta de Inconstitucionalidade (ADIN), mas, também, devido ao incremento da temática constitucional .

O Supremo é composto por onze ministros e a indicação para o cargo depende de três requisitos constitucionais: 35 a 65 anos de idade, notável saber jurídico e reputação ilibada. A indicação é do Presidente/ Presidenta da República, ad referendum (via sabatina) do Senado Federal. Aprovado, o indicado é nomeado pelo Presidente/Presidenta da República. Ao longo da história do STF, que conta mais de 160 ministros, apenas cinco nomes indicados foram rejeitados ${ }^{8}$. O que não prova, mas sugere, que o procedimento de sabatina e aprovação é meramente formal. A tabela 1, a seguir, descreve a composição atual do STF:

\footnotetext{
${ }^{7}$ Constituição extensa e formal, que, à moda de Midas, torna constitucional todo assunto que toca(emendas) ou tocou(Poder constituinte originário).

${ }^{8}$ Essas rejeições ocorreram no governo de Marechal Floriano (1891/1894). Isto porque foram indicados dois generais e um médico, os quais não possuíam "saber jurídico". E, diante da insatisfação com as decisões do STF durante seu governo, para que não houvesse quórum mínimo para as decisões, deixou de prover sete vagas existentes.
} 
Sociologias, Porto Alegre, ano 15, no 33, mai./ago. 2013, p. 206-246

\begin{tabular}{|c|c|c|c|c|}
\hline Ministro & Indicação & $\begin{array}{c}\text { Cargo ocupado antes da } \\
\text { nomeação }\end{array}$ & Posse & $\begin{array}{l}\text { Proje- } \\
\text { ção de } \\
\text { Saída* }\end{array}$ \\
\hline Rosa Weber & \multirow{2}{*}{ Dilma Rousseff } & $\begin{array}{l}\text { Ministra do Superior } \\
\text { Tribunal do Trabalho }\end{array}$ & $19 / 12 / 2011$ & 2018 \\
\hline Luiz Fiux & & $\begin{array}{l}\text { Ministro do Superior Tribu- } \\
\text { nal de Justiça }\end{array}$ & 03/03/2011 & 2023 \\
\hline $\begin{array}{l}\text { José Antonio } \\
\text { Toffoli }\end{array}$ & \multirow{6}{*}{$\begin{array}{l}\text { Luis Inácio } \\
\text { Lula da Silva }\end{array}$} & Advogado-geral da União & $23 / 10 / 2009$ & 2037 \\
\hline Carmen Lúcia & & $\begin{array}{c}\text { Procuradora do Estado } \\
\text { de Minas Gerais }\end{array}$ & $21 / 06 / 2006$ & 2024 \\
\hline $\begin{array}{c}\text { Ricardo } \\
\text { Lewandowski }\end{array}$ & & $\begin{array}{l}\text { Desembargador do } \\
\text { Estado de São Paulo }\end{array}$ & $16 / 03 / 2006$ & 2018 \\
\hline $\begin{array}{l}\text { Joaquim } \\
\text { Barbosa }\end{array}$ & & Procurador da República & $25 / 06 / 2003$ & 2024 \\
\hline Ayres Britto & & Advogado/Professor & $25 / 06 / 2003$ & 2012 \\
\hline Cezar Peluso & & $\begin{array}{c}\text { Desembargador do Tribunal } \\
\text { de Justiça do Estado } \\
\text { de São Paulo }\end{array}$ & $25 / 06 / 2003$ & 2012 \\
\hline Gilmar Mendes & $\begin{array}{c}\text { Fernando } \\
\text { Henrique Cardoso }\end{array}$ & Advogado-geral da União & 20/06/2002 & 2025 \\
\hline Marco Aurélio & $\begin{array}{l}\text { Fernando Collor } \\
\text { de Mello }\end{array}$ & $\begin{array}{c}\text { Corregedor-geral } \\
\text { da Justiça do Trabalho }\end{array}$ & 13/06/1990 & 2016 \\
\hline Celso de Mello & José Sarney & $\begin{array}{l}\text { Secretário-geral da } \\
\text { Consultoria-geral } \\
\text { da República }\end{array}$ & 17/08/1989 & 2015 \\
\hline
\end{tabular}

* Aposentadoria compulsória aos 70 anos de idade. 
A forma de escolha dos ministros tem sido questionada ${ }^{9}$. Além disso, indaga-se, considerando que não são eleitos democraticamente, o quanto é legítimo e democrático o exercício da função política pelos ministros do Supremo.

Nesse ponto, frise-se que o processo de escolha dos ministros não joga papel decisivo no caráter político das decisões por eles tomadas. Obviamente, a alternância ditada pela limitação temporal (mandatos) poderia ensejar importantes distinções na substancialidade das decisões, mas, em todo caso, estas não deixariam de ser políticas. Afirma-se isto, na medida em que, formalmente, as decisões do Supremo podem ser insertas num quadro institucional, longe de serem, quanto ao alcance e consequências, a expressão de preferências individuais. O papel efetivamente decisivo reside no fato de que, exatamente por ser o STF uma instituição política par excellence, os seus ministros, sejam quem forem, são colocados na posição de tomar decisões políticas, isto é, coletivamente vinculantes. Assim, o credo religioso, o ser negro ou branco, homem ou mulher, liberal ou conservador não deixa de ser importante quando se pensa na posição que o ministro pode assumir em relação ao aborto, à proteção da mulher ou ao sistema de cotas. Todavia, ao não se perceber o STF como uma instituição originariamente, e não incidentalmente, política, aí sim, torna-se um problema o fato de um ministro, com essa ou aquela inclinação associada à sua trajetória social ou profissional, permanecer 20 ou 30 anos no poder. Isso soa antidemocrático, na medida em que a população se vê alijada de influenciar na alternância das prefe-

\footnotetext{
${ }^{9}$ Interessante registrar, já que se trata de um artigo vinculado a uma tese de doutorado, que, do início de nossas pesquisas até o momento em que revisamos este texto, foi apresentada a Proposta de Emenda à Constituição - PEC no 342/2009. Esta PEC, da lavra do partido PC do $\mathrm{B}$, pretende justamente alterar o modo de escolha dos ministros do STF e tornar os cargos limitados por mandato de 11 anos.
} 
rências. Um ministro pode ser favorável ou desfavorável ao aborto, mas, seja como for, pelo uso de um código binário redutor de complexidade, o fato é que decidirá acerca de uma questão cujas consequências recairão sobre a vida de milhares de pessoas, sem que estas tenham participado do processo decisório.

Os ministros do STF estão adstritos tanto à agenda quanto ao alcance e consequência de suas decisões. Claro está, nem uma coisa nem outra é institucionalmente traçada, de sorte que os ministros, além de não decidirem o que decidir, não têm controle efetivo sobre o corte longitudinal do que decidem.

O quadro teórico dentro do qual inserimos esta assertiva nos foi fornecido, em termos de síntese, pela antropóloga Mary Douglas (2007). Para dar conta da insuficiência vislumbrada nas teorias de corte econômico da abordagem das relações humanas, especialmente as expoentes da escolha racional e da ação coletiva, Douglas reafirmou, em termos teóricos, as bases solidárias do relacionamento humano. As questões levantadas têm um caráter marcadamente epistemológico e são consistentes com o relevo dado por uns, e veemente negado por outros, às bases sociais do pensamento e, logo, do conhecimento individual. O esforço foi o de demonstrar, contra as teorias egoísticas da escolha racional, que grande parte do que um indivíduo pensa e conhece não advém de seu contato direto com o mundo e de suas habilidades de observador/receptor. Ao longo da vida, o indivíduo vai recebendo, mais pela informação do que pela observação, categorias com as quais constrói o mundo, que é o mundo para ele, sem se colocar a questão de se existe um mundo mais real do que este que lhe é dado ao longo da socialização.

O quadro teórico exposto sugeriu-nos uma pista para a resolução do quebra-cabeça que iremos chamar de a autonomia do robot, isto é, se assumimos, em qualquer situação humana, que dez ou dezenas de indiví- 
duos são funcionalmente autônomos, livres, independentes, então como podemos explicar que, ao cabo de pares e pares de anos, esses 'robôs' tenham feito, ao fim e ao cabo, descontadas as nuances e circunstâncias, sem força de alteração ontológica, as mesmas coisas (habitus)? Obviamente, alguém pode objetar não se tratar de nenhum quebra-cabeça e que o fato de os 'robôs' fazerem a mesma coisa, trilharem o mesmo caminho, é uma decorrência da própria autonomia. Não se aceita a objeção. Todos sabem, por experiência direta ou não, que um ser autônomo, por excelência, ao longo do tempo, tenderá a se afastar de um eixo dado. De outro lado, aquilo em que se apoia para fortalecer o pathos é exatamente o caráter instável, aberto e interpretativo do paradigma que todos os ministros do STF estão obrigados a seguir.

A influência exercida pelas instituições é de tal maneira acentuada, que sequer é notada qualquer mudança. O pensamento individual é ligado a um piloto automático ${ }^{10}$, de modo que, quando o indivíduo busca chegar a uma decisão, a resposta só parece correta quando apoia o pensamento institucional ${ }^{11}$, que já se encontra em sua mente. Isso, porque as instituições, visando conferir uniformidade, inserem as categorias de pensamento em seus membros, do mesmo modo que fixam as identidades. Ou seja, os membros do grupo são remodelados para que se adequem às categorias, bem como aos compromissos institucionais. É necessário que os membros compartilhem essas mesmas categorias de pensamento, para que exista solidariedade entre eles (Douglas, 2007).

O STF não é uma instituição política porque os ministros que o compõem tenham trilhado uma trajetória política (não necessariamente). Em verdade, os ministros tomam decisões políticas independentemente de

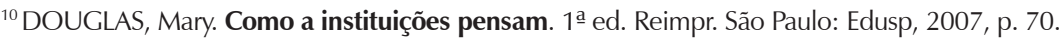
${ }^{11}$ DOUGLAS, Mary. Como a instituições pensam. 1aㅡ ed. Reimpr. São Paulo: Edusp, 2007, p. 18.
} 
sua trajetória, a partir do instante e porque se tornam ministros (inserção institucional). A trajetória social ou profissional de um dado ministro joga, evidentemente, um papel decisivo na elaboração e fixação do conteúdo de dada decisão. Mas, efetivamente, o cunho político ou governista da decisão é inerente à instituição (STF). O ministro Joaquim Barbosa, por exemplo, ocupou o cargo de Procurador da República, e não se pode dizer que sua trajetória tenha contemplado qualquer radicação aos espaços de poder, como esse termo é entendido na Ciência Política ${ }^{12}$. Do mesmo modo, a ministra Carmem Lúcia, embora tenha sido procuradora geral do Estado de Minas Gerais, prevalentemente, foi procuradora de carreira do Estado de Minas Gerais e professora universitária. Considerando que a corte é composta de apenas 11 ministros e que não são incomuns decisões monocráticas, estes dois exemplos parecem capazes de validar a afirmação de que uma trajetória alocada aos espaços de poder não é, ou não é necessariamente, uma variável relativamente à atuação política desse tipo de corte. A predita trajetória há de ser levada em conta, quando se procura uma previsibilidade, com fim de influência ou não, quanto ao caráter governista, posicionista, conservador, moderado ou liberal, do posicionamento deste ou daquele ministro ou ministra. Do ponto de vista das pesquisas que dão suporte a este artigo, a centralidade reside na atuação política governamental da instituição do STF, independentemente do conteúdo das decisões. De mais a mais, os juízes da assim chamada

\footnotetext{
12 Note-se bem: não se está afirmando que o cargo de Procurador da República não coloque institucionalmente o seu ocupante em posição de tomar decisões políticas no sentido em que usamos a expressão 'decisão política' neste artigo. O que, de resto não se sustentaria, apenas se pensando nas ações civis públicas de grande porte e com efeito erga omnes. O que se diz é que, claramente, a voz 'espaços de poder' tem como referente um tipo específico de trajetória no assim chamado mundo político e nos círculos de poder, o qual não se confunde com o exercício de um cargo que, nada obstante as consequências políticas das decisões de seus membros, tem marcos discursivos e normativos estritamente jurídicos.
} 
base do Poder Judiciário, tendo em vista a abordagem institucionalista das referidas pesquisas, integram, eles próprios, hodiernamente, um sistema cuja unidade é conferida precisamente pelo STF ${ }^{13}$.

Nesse contexto, a literatura mais recente mostra-se atenta à atuação dos tribunais no cenário político, especialmente, a do Supremo Tribunal Federal, rendendo-se à sua importância e à necessidade de maiores e melhores aportes acadêmicos que gerem explicações válidas e úteis.

Matthew M. Taylor e Luciano Da Ros ${ }^{14}$, em alentado artigo, acentuaram esta importância do STF no cenário político. Comparando os usos das ADIN's no período dos governos FHC e Lula, estes cientistas buscaram identificar variações qualitativas e quantitativas e, então, explicá-las. Um diálogo com estes autores permite estabelecer que, embora ciosos da atuação política do STF e de suas implicações nas políticas e decisões partidárias, eles filiam-se a uma corrente que pode ser identificada, grosso modo, como aquela que tem uma visão instrumental do Supremo Tribunal Federal. Observam os autores filiados à dita corrente que os partidos políticos fazem o que chamam de uso partidário oposicionista da Corte. Não há reparos a fazer quanto às conclusões do trabalho consultado, muito menos à acurada análise do conteúdo e quantidade de ADIN's em cada período estabelecido. Todavia, esta parte da literatura sobre o assunto serve para evidenciar que, na representação social da comunidade jurídica brasileira, com aportes importantes na comunidade científica de

\footnotetext{
${ }^{13}$ Em outro estudo, explora-se o Poder Judiciário como uma rede compartilhada de saberes, crenças e representações. Busca-se identificar, na instituição STF (e Cortes congêneres) um dos mecanismos redutores e conformadores da provável complexidade das milhares de decisões judiciais tomadas no país todos os anos. Isto é tanto mais relevante, dado que, no sistema constitucional (rectius: político) brasileiro, cada juiz é um intérprete autorizado da Constituição da República.

${ }^{14}$ Segundo estudo realizado, o PGR tem maiores chances de obter um posicionamento favorável no STF. DA ROS, Luciano; TAYLOR, Mathew. Os Partidos Dentro e Fora do Poder: A Judicialização como Resultado Contingente da Estratégia Política. DADOS - Revista de Ciências Sociais, Rio de Janeiro, v. 51, n. 4, p. 825-864, 2008.
} 
outros campos, o Poder Judiciário, em especial o STF, está colocado, por força da imagem forte da separação de poderes, fora do sistema político. Somente a partir da assunção desta representação social é que faz sentido pensar no STF como um instrumento à disposição da classe política. Neste artigo, ao revés, assume-se que o STF, enquanto elemento do sistema político, opera com seus próprios materiais e acredita-se que não possua um caráter instrumental relativamente aos demais elementos do sistema. O aprofundamento das pesquisas pode revelar, inclusive, o que se opera hoje como hipótese, ou seja, de que os agentes provocadores da atuação do STF são eles, sim, instrumentos de política da Corte. O artigo citado, por exemplo, trabalhou o acionamento do STF por meio de partidos políticos e através de ADIN's. Parece, dentro da lógica adotada, que um ator como o Procurador Geral da República (PGR), cujo assento atual e matriz histórica ${ }^{15}$ estão dentro do Tribunal, não pode ser desconsiderado, ou melhor, sua consideração, por questões metodológicas, pode conduzir a outros resultados ${ }^{16}$.

\section{A formação da agenda do STF: elitismo ou democracia}

A construção da hipótese de que o STF opera, funcionalmente, como órgão de governo, guiou-se na busca de resposta a duas perguntas: Qual o conteúdo da agenda do STF? Como esta agenda é construída? Através das respostas a estas indagações, buscamos verificar se o conteúdo da Agenda do Supremo é, ou não político. Assim como, perceber quais são os principais atores que constroem esta Agenda.

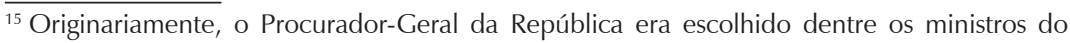
Supremo Tribunal Federal

${ }^{16}$ SANTOS, André Marenco dos e DA ROS, Luciano. Caminhos que levam à Corte: carreiras e padrões de recrutamento dos ministros dos órgãos de cúpula do Poder Judiciário brasileiro (1829-2006). Revista de Sociologia e Política [online]. 2008, vol.16, n.30, pp. 131-149.
} 
Considerando a constante atuação do STF em questões polêmicas e relevantes divulgadas nos meios de comunicação, optou-se por selecionar, para a construção da Agenda, decisões que ganharam destaque nos jornais de grande circulação no país, desde o início do Governo de Fernando Henrique Cardoso (FHC) ${ }^{17}$. De mais a mais, vale destacar que não foi considerado o conteúdo das decisões, deram-se neste ou naquele sentido, mas, sim, a construção da agenda e seu caráter político de afetação da vida de todo dia.

Escolhidos os jornais ${ }^{18}$, foi realizada a leitura das notícias veiculadas no período estabelecido. As notícias constatadas foram relacionadas e divididas. Primeiramente, de acordo com o governo e, em seguida, de acordo com a categoria ${ }^{19}$. Após a divisão, o conteúdo da Agenda, apresentouse da seguinte forma, conforme se verifica na tabela 2 (a e b):

\footnotetext{
${ }_{17}$ Portanto, estabeleceu-se para a construção da Agenda, o período compreendido desde o primeiro mandato do governo FHC (01/01/1995 a 31/12/2002), passando pelos dois mandatos do governo Lula (01/01/2003 a 31/12/2010) e o primeiro ano do governo Dilma Rousseff (01/01/2011 a 31/12/2011). Todavia, apesar de ter incluído o primeiro ano do governo Dilma Rousseff, não foi estabelecida uma agenda para este período, uma vez que verificamos que os julgamentos ocorridos em 2011 já estavam na agenda do STF.

${ }^{18}$ Selecionou-se os seguintes jornais: Folha de São Paulo, Correio Braziliense, Correio do Povo e Estado de Minas.

${ }^{19}$ Para a classificação das notícias relacionadas estabelecemos cinco categorias distintas, quais sejam: econômica, social, meio ambiente, política criminal e cultura.
} 
Tabela 2a. Agenda

\begin{tabular}{|c|c|}
\hline & Governo FHC \\
\hline \multirow[t]{2}{*}{ Econômica } & $\begin{array}{l}\text { - Constitucionalidade da Lei de Informática } \\
\text { - Venda de distribuidoras da CEEE (Companhias de Energia Elétrica Estaduais) } \\
\text { - Inconstitucionalidade dos artigos das Constituições Estaduais (RJ) que impediam } \\
\text { o Executivo de decidir sobre privatizações } \\
\text { - Receita COFINS (empresas de energia elétrica, telecomunicações, mineração, } \\
\text { combustíveis e derivados do petróleo devem contribuir para o financiamento da } \\
\text { Seguridade Social - COFINS, e do Programa de Integração Social - PIS) } \\
\text { - Prorrogação do CPMF } \\
\text { - Lei de responsabilidade fiscal } \\
\text { - Benefícios fiscais às empresas dos setores de farinha, trigo e carne }\end{array}$ \\
\hline & $\begin{array}{l}\text { - Racionamento de energia elétrica } \\
\text { - Racionamento de energia elétrica } \\
\text { - Correção do FGTS } \\
\text { - Aumento do servidores estaduais } \\
\text { - Reajuste salarial dos servidores federais } \\
\text { - Limite de gastos com o funcionalismo público } \\
\text { - Anistia de multa eleitoral } \\
\text { - Cobrança de Inativos (impede) } \\
\text { - Auxílio-moradia para juízes } \\
\text { - Contribuição previdenciária dos funcionários da União } \\
\text { - Reeleição }\end{array}$ \\
\hline Social & $\begin{array}{l}\text { - Impeachment (altera regras do processo de impeachment do governador do } \\
\text { - CPtado de SC) } \\
\text { gada sem prévia autorização do Judiciário } \\
\text { - Reforma Agrária } \\
\text { - Concessão de licença remunerada de } 120 \text { dias à mãe adotiva } \\
\text { - Inviolabilidade das mensagens de correio eletrônico } \\
\text { - Verticalização } \\
\text { - Reforma da Previdência (suspende) } \\
\text { - Sigilo bancário - cláusula pétrea } \\
\text { - Gratuidade das certidões de nascimento e de óbito emitidas pelos cartórios } \\
\text { - Reajuste salarial juízes }\end{array}$ \\
\hline
\end{tabular}




\begin{tabular}{|c|c|}
\hline & Governo Lula \\
\hline Econômica & $\begin{array}{l}\text { - Proibição Amianto } \\
\text { - } \text { CDC e atividades de natureza bancária, financeira, de crédito e securitária } \\
\text { riores a junho de dispositivos que beneficiavam usuários dos planos de saúde ante- } \\
\text { - } \quad \text { Legalidade do Monopólio dos Correios } \\
\text { - } \text { Inconstitucionalidade da norma que ampliou a base da cálculo da contribuição } \\
\text { ção Nacional (PIS) } \\
\text { - Simples Nacional } \\
\text { - Constitucionalidade da restituição de ICMS pago antecipadamente }\end{array}$ \\
\hline Social & 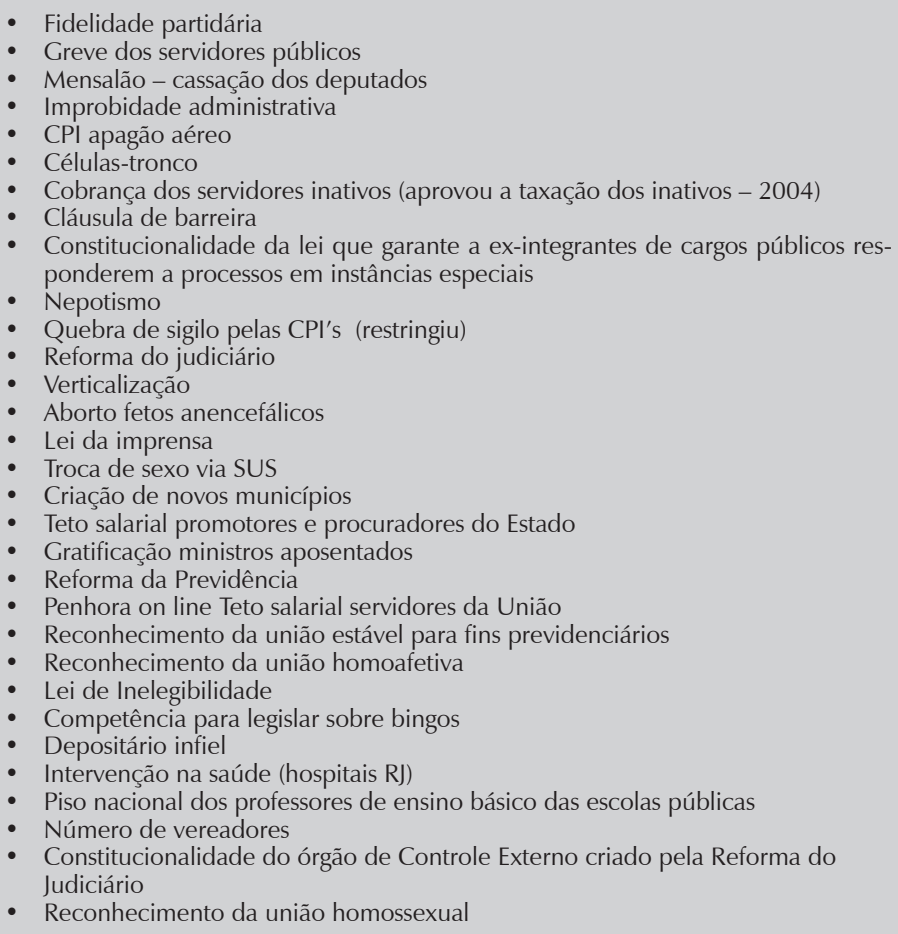 \\
\hline $\begin{array}{l}\text { Meio } \\
\text { Ambiente }\end{array}$ & $\begin{array}{l}\text { - Demarcação da área indígena Raposa Terra do Sol } \\
\text { - Continuidade das obras de transposição do Rio São Francisco } \\
\text { - Importação de pneus usados }\end{array}$ \\
\hline
\end{tabular}


Continuação...

\begin{tabular}{|c|c|}
\hline & Governo Lula \\
\hline $\begin{array}{l}\text { Política } \\
\text { Criminal }\end{array}$ & 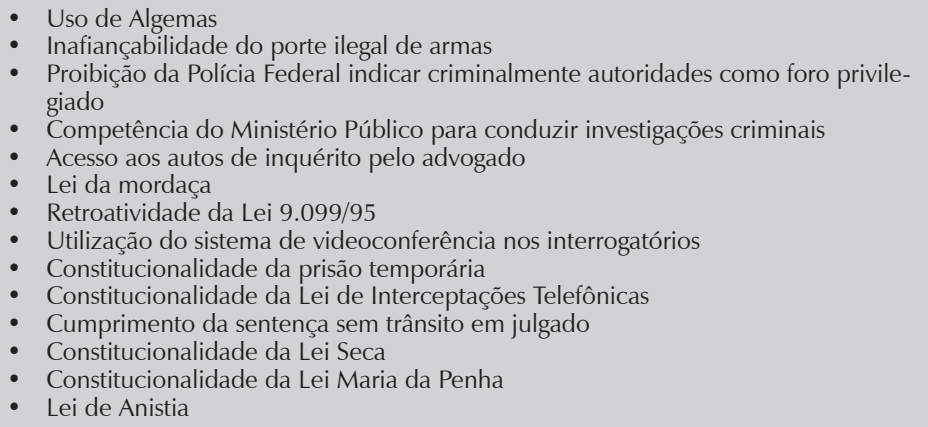 \\
\hline Cultura & $\begin{array}{l}\text { - Política de cotas } \\
\text { - Constitucionalidade do Prouni } \\
\text { - Constitucionalidade do parecer que determina que as instituições de ensino supe- } \\
\text { rior são obrigadas a abrir vagas, para militares ou dependentes, em caso de transfe- } \\
\text { rência no interesse do serviço } \\
\text { - Exigência do diploma de graduação para o exercício do jornalismo }\end{array}$ \\
\hline
\end{tabular}

Observando o conteúdo da Agenda dos dois governos, facilmente percebemos que houve um grande aumento no número de questões de repercussão política ou social levadas ao Supremo. Com a crescente atuação do STF nessas questões, as quais, como já exposto, considerando a divisão de poderes inserida na Constituição Federal, são de competência do Congresso Nacional e da Presidência da República, muito se tem discutido sobre a "judicialização da política", denominação dada ao fenômeno da interferência judicial, ou seja, do papel ativo desempenhado pelo STF no cenário político. Nesse sentido, há consenso, quanto à atuação do Supremo em questões políticas. A discussão concentra-se, principalmente, no que se refere à legitimidade de tal atuação.

Mas a atuação política do STF, quando percebida, é percebida como contingente e, portanto, para os críticos habituados à tripartição dos po- 
deres do Estado, como usurpadora das funções legislativas e propriamente políticas que estariam a cargo de outras instituições. Não é raro que, a partir desta percepção, se construam críticas ao que se chama omissão do Congresso Nacional. Termo que sintetiza não só a percepção, mas também as abordagens teóricas e empíricas dos problemas suscitados pela atuação do Supremo é "judicialização". Este termo é emblemático, uma vez que judicializar significa tornar do judiciário, colocar debaixo dos seus olhos o que, como regra, ali não deveria estar. É importante ressaltar a objeção que fazemos à expressão "judicialização da política", pois, na hipótese desta pesquisa, onde consideramos que o STF é um órgão institucionalmente político, não há como conceber que exista uma "judicialização da política".

Em relação à atuação do STF, destaca-se que, ao examinar os dados referentes à evolução da movimentação processual, constatamos que, após a promulgação da Constituição de 1988, aumentou significativamente a movimentação processual do Supremo. Conforme evidenciam os dados da tabela 3:

Tabela 3. Movimentação Processual do STF

\begin{tabular}{ccccccc}
\hline $\begin{array}{c}\text { Movimentação } \\
\text { STF }\end{array}$ & $\mathbf{1 9 6 0 / 1 9 6 9}$ & $\mathbf{1 9 7 0 / 1 9 7 9}$ & $\mathbf{1 9 8 0} / \mathbf{1 9 8 9}$ & $\mathbf{1 9 9 0 / \mathbf { 1 9 9 9 }}$ & $\mathbf{2 0 0 0 / \mathbf { 2 0 0 9 }}$ & $\mathbf{2 0 1 0} / \mathbf{2 0 1 1}$ \\
\hline $\begin{array}{c}\text { Proc. } \\
\text { Protocolados } \\
\text { Proc. }\end{array}$ & 78.219 & 72.133 & 163.950 & 326.493 & 1074.695 & 135.688 \\
$\begin{array}{c}\text { Distribuídos } \\
\text { Julgamentos }\end{array}$ & $\mathbf{7 5 . 6 5 8}$ & 74.558 & 149.533 & 297.778 & 865.195 & 79.123 \\
$\begin{array}{c}\text { Acórdãos } \\
\text { Publicados }\end{array}$ & $\mathbf{6 4 . 4 3 9}$ & $\mathbf{3 7 . 8 8 4}$ & $\mathbf{4 1 . 8 6 0}$ & $\mathbf{9 1 . 4 5 1}$ & $\mathbf{1 4 0 . 3 0 8}$ & $\mathbf{2 4 . 9 0 7}$ \\
\hline
\end{tabular}

Fonte: Supremo Tribunal Federal (www.stf.jus.br). 
Os dados demonstram que, desde o ano 2000, esse aumento tem sido ainda mais expressivo. O número de processos recebidos e o número de julgamentos realizados pelo STF, no período compreendido entre o ano 2000 e 2011, ultrapassam o número de um milhão. Estes dados são facilmente visualizados no gráfico 1 :

\section{Gráfico 1- Movimentação Processual STF}

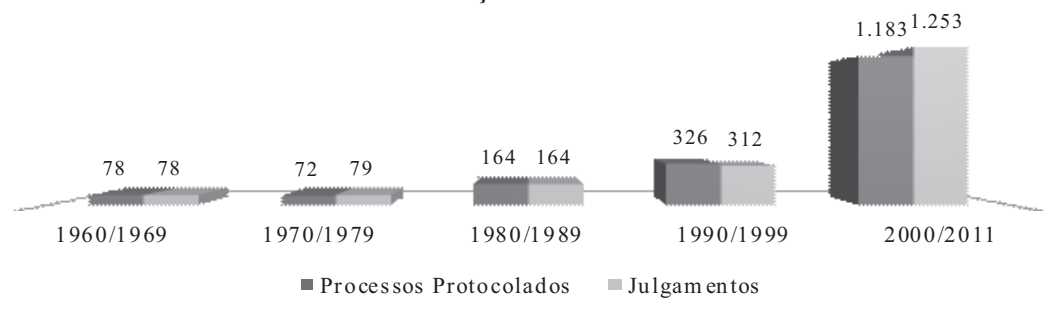

Esse aumento também se deve ao fato de que a Constituição de 1988, em seu artigo 103, ampliou o número dos atores legitimados a propor a ADIN, que até então era exclusiva do Procurador-Geral da República. Entretanto, o Supremo, por entendimento jurisprudencial, exige de alguns dos atores previstos no referido artigo a pertinência temática, ou seja, que haja relação entre a norma questionada e os interesses específicos do ator. A tabela 4 a seguir expõe os números de ADIN's propostas de acordo com os respectivos atores: 
Tabela 4. Ações Diretas de Inconstitucionalidade por Legitimados

\begin{tabular}{lcc}
\hline Atores Legitimados & Quantidade & $\%$ \\
\hline Presidente da República & 8 & 0,2 \\
Mesa do Senado Federal & 1 & 0,0 \\
Mesa da Câmara dos Deputados & 0 & 0,0 \\
Governador de Estado ou do Distrito Federal (DF) & 1.109 & 23,9 \\
Mesa da Assembleia Legislativa ou Câmara Legislativa do DF & 53 & 1,1 \\
Procurador-Geral da República & 947 & 20,4 \\
Conselho Federal da OAB & 206 & 4,4 \\
Partido Político com representação no Congresso Nacional & 814 & 17,5 \\
Confederação Sindical ou Entidade de Classe de Âmbito Nacional & 1.145 & 24,6 \\
Mais de 1 Legitimado * & 3 & 0,1 \\
Outro (Legitimados) & 360 & 7,7 \\
\hline Total & $\mathbf{4 . 6 4 6}$ & $\mathbf{1 0 0} \%$ \\
\hline
\end{tabular}

Fonte: Supremo Tribunal Federal (www.stf.jus.br). Dados atualizados até janeiro de 2012.

* Confederação Sindical ou Entidade de Classes e Partido Político

A importância em destacarmos quem são os atores atuantes na construção da agenda do STF está precipuamente no fato de ser através deles que as questões são levadas ao Supremo, ou seja, é por eles que o Supremo é acionado e chamando a se manifestar. E, facilmente percebemos, pela representação da tabela, que os agentes políticos são os que mais participam da construção da agenda do STF. Ou, dito de outro modo, a agenda com a qual o STF se movimenta é uma agenda política.

Com efeito, o resultado deste trabalho demostra que a agenda do STF é uma agenda política, se vista tanto do aspecto de sua formação como do aspecto de seu conteúdo e realização. Isto é problemático, precisamente porque parece disfuncional relativamente ao modelo de democracia participativa.

Nesse contexto, cumpre ressaltar que em estudos em que se analisou a atuação do legitimados ativos admitidos e não admitidos pelo Supremo, conclui-se que "a atuação da corte tem se pautado por restringir o acesso" 20.

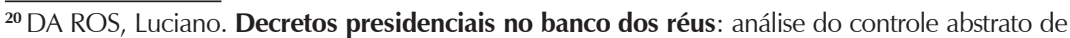
constitucionalidade de medidas provisórias pelo Supremo Tribunal Federal no Brasil (1988-2007). Disponível em: <http://www.lume.ufrgs.br/handle/10183/13819>. Acesso em: 20 jun. 2012. 


\section{Metadiscursividade: em busca da legitimação}

Utilizando como referencial teórico o estudo do metadiscurso interpessoal de Hyland (2005), o qual forneceu elementos suficientes para a pesquisa pretendida, e partindo do pressuposto de que essa função legiferante exercida pelos ministros do STF Ihes causa um certo desconforto, .buscamos, através de uma leitura atenta dos votos por eles proferidos, identificar a forma como se posicionam na construção dos seus discursos, ou seja, identificar os marcadores metadiscursivos que indicassem as estratégias discursivas utilizadas.

Necessário estabelecer que metadiscursos são estratégias de comunicação que possibilitam ao autor organizar seus textos de modo a engajar os leitores, sinalizando a forma como estes últimos devem recepcioná-los. Demonstram a preocupação do autor em utilizar elementos que possibilitem a seus textos produzir os efeitos desejados (Hyland, 2005).

Segundo Hyland, o metadiscurso é um dos meios pelos quais o escritor envolve o leitor, construindo com este uma relação para facilitar a comunicação. Acrescenta, ainda, que, tendo o escritor conhecimento de para quem o texto está direcionado, pode usar formas de persuasão e amoldá-lo às expectativas desse leitor, usando elementos de persuasão para envolvê-lo e influenciá-lo a adotar, ou a concordar com, as posições e atitudes estabelecidas. Isso porque permite que seja oferecida uma apresentação mais acreditável, e efetivamente convincente, garantindo antecipadamente uma maior aceitação por parte do leitor. Ou seja, o conhecimento prévio permite ao escritor "negociar" com o leitor, pois, prevendo suas atitudes, pode decidir quais os efeitos que lhe pretende causar.

Hyland aponta, para o metadiscurso interpessoal, duas categorias: interativo e interacional, a primeira, constituída dos metadiscursos que envolvem o leitor no texto; e a segunda daqueles que ajudam o leitor a se guiar através do texto. É a categoria interacional que se enquadra sa- 
tisfatoriamente aos objetivos propostos por esta pesquisa, em particular, os marcadores de ênfase e de atenuação, os quais consistem em estratégias de comunicação para ampliar, ou atenuar a força do que diz o autor. Ou seja, são utilizados para identificar as possibilidades e indicar o espaço que o autor está disposto a negociar, permitindo que determine o comprometimento dos leitores, decidindo como as informações serão interpretadas, a forma como serão recepcionadas e, consequentemente, os efeitos que causarão.

Os enfatizadores (Boosters) são expressões utilizadas com o objetivo de ampliar a força do posicionamento tomado pelo autor, enfatizam a certeza do que foi dito, apontam o fechamento de visões contraditórias não possibilitando alternativas. Por outro lado, os atenuadores (Hedges) são expressões que possibilitam diminuir o comprometimento do autor com seus posicionamentos, indicam a decisão do autor em deixar o diálogo em aberto, ou seja, possibilita apresentar a informação como uma opinião em lugar de um fato, abrindo uma negociação para reconhecer pontos de vista alternativos.

É importante ressaltar que, segundo Hyland, não existem critérios estabelecidos para a identificação dos marcadores metadiscursivos:

[...] não há nenhum critério lingüístico simples para identificação do metadiscurso. Na realidade, o metadiscurso pode ser visto como uma categoria aberta, na qual os escritores podem acrescentar elementos novos de acordo com as necessidades do contexto. Até mesmo adotando uma abordagem funcional, há numerosos modos que nos tornam capazes de revelar, em nossos textos, tanto a nós mesmos, como os nossos propósitos, e há uma gama potencialmente enorme de elementos lingüísticos que podem realizar estas funções. (Hyland, 2005, p. 27 - tradução nossa)

Desse modo, não se tratando de uma categoria fechada, a identificação dos marcadores metadiscursivos pode ser realizada através da 
leitura dos textos, visando descobrir os elementos utilizados pelo autor que apontem sua intenção de engajar o leitor, persuadindo-o a participar e influenciando-o na recepção de seus textos.

Estabelecidos os pressupostos teóricos, o próximo passo foi a seleção dos votos que comporiam a base material na qual seriam procurados os marcadores metadiscursivos ${ }^{21}$. Ler voto por voto de todos os julgados tornaria a pesquisa inexequível, mormente se considerada a própria hipótese de trabalho, segundo a qual, toda decisão do STF é exercício precípuo de sua função política. Diante disso, partimos do critério da repercussão midiática das decisões, utilizado para estabelecer os temas em pauta na agenda do STF (tabela 2). A partir da agenda estabelecida, foram, aleatoriamente, selecionadas 30 das questões em debate no Supremo. Após, foi realizada a análise, na íntegra, destes 30 acórdãos, examinando atentamente o voto de cada ministro ${ }^{22}$. A partir dos acórdãos analisados, buscando viabilizar a exposição da análise ${ }^{23}$, foram selecionados dez temas da agenda, sendo, nessa última seleção, também utilizado o critério midiático.

Os dez temas selecionados foram: a inconstitucionalidade da Lei de Biossegurança, a qual dispõe sobre as pesquisas científicas com célulastronco embrionárias (ADIN - 3510); a prática do nepotismo (Recurso Extraordinário - RE - 579.951); a exigência do diploma de jornalismo para o exercício da profissão (RE 511.961-1); a Lei de Inelegibilidade (Arguição de Descumprimento de Preceito Fundamental - ADPF - 144); o direito ao acesso aos autos de inquérito pelo advogado (PSV 1); o direito do exercício de greve dos servidores públicos (Mandado de Injunção - MI

\footnotetext{
${ }^{21}$ Os votos foram obtidos no site do STF. Disponível em: <http://www.stf.jus.br >.

${ }^{22}$ Lembre-se que esta pesquisa não teve o objetivo de verificar em que sentido a decisão foi tomada, mas sim identificar a forma como os ministros constroem seus discursos.

${ }^{23}$ Importante esclarecer que os votos dos ministros são muito extensos, o que torna impossível a exposição de toda a análise realizada.
} 
- 712/708/670); o uso de algemas (Habeas Corpus - HC - 91952); a fidelidade partidária (Mandado de Segurança - MS - 26.602); a prisão do depositário infiel ( RE 466.343/349.703); e a Lei de Imprensa (ADPF 130).

É importante esclarecer, em reforço, que a repercussão do tema ou da decisão nos meios de comunicação social (no caso, jornais) foi um critério pragmático. De um ponto de vista científico, uma decisão pode ser política e não ser repercutida na imprensa, eis que o que the confere o caráter político são seus efeitos coletivamente vinculantes e não a repercussão ${ }^{24}$.

Construída a base material (discursiva), passamos à leitura dos votos. Nesse ponto, parece adequada uma explicação. O STF, conforme já exposto, é composto de 11 ministros. O sistema de tomada de decisões é o da maioria. Por força disto, dado um tema qualquer da agenda, cada ministro toma sua própria decisão. A decisão de cada ministro compõe-se de duas partes. Na primeira, são expostas as questões em debate e a linha de argumentação daquele ministro. Na segunda, o ministro expõe a decisão propriamente dita, declarando-se favorável ou desfavorável ao que foi proposto. A soma dessas duas partes é conhecida no meio jurídico pela palavra voto. Assim, depois que cada ministro expõe seu voto, estes são contados e proclama-se a decisão por maioria. A decisão final, já somados os votos, recebe o nome de acórdão. Pois bem, nesta pesquisa o foco foi cada voto e, dentro deste, contou menos a decisão e mais a extensa parte na qual o ministro discorre acerca do tema e expõe seus argumentos.

Isso se deveu ao propósito de realizar uma percepção de segundo grau, isto é, queríamos perceber como os ministros percebem a Agenda

\footnotetext{
${ }^{24}$ Segundo David Easton (Easton, 1963), decisões políticas são aquelas que traduzem uma alocação autoritativa de valores na sociedade.
} 
com a qual realmente trabalham e como lidam com esta percepção no quadro da teoria da separação de poderes. Além disso, visava-se identificar como os ministros se comportam quando decidem questões consideradas eminentemente políticas. Buscamos perceber como os ministros constroem seus discursos nessas decisões, e, sobretudo, analisar o posicionamento que tomam, procurando identificar se reconhecem ou não sua atuação na função legislativa e, no caso de reconhecerem, como se posicionam perante essa atuação, se a consideram legítima ou ilegítima.

Para tanto, na leitura dos votos, buscamos constatar a presença dos marcadores metadiscursivos de ênfase (boosters) e de atenuação (hedges) ${ }^{25}$ para, através destes, identificar e analisar a construção e a função do metadiscurso dentro do discurso principal. Além disso, procuramos constatar se há preocupação dos ministros em articular e construir uma interação com o leitor, ou seja, se há preocupação em enfatizar ou atenuar suas decisões, direcionando o leitor para que seus textos produzam, neles, os efeitos desejados.

Feitas essas considerações, passamos a expor alguns trechos dos votos examinados, nos quais se observa que, realmente, há um metadiscurso nos votos proferidos pelos ministros do STF, ou seja, estes se utilizam de elementos gramaticais (marcadores metadiscursivos), buscando interação com os leitores. A seguir, os marcadores metadiscursivos identificados:

[...], o Supremo Tribunal Federal vem decidindo questões importantes, [...], sem que se possa cogitar de que tais questões teriam sido melhor decididas por instituições majoritárias, e que assim teriam maior legitimidade democrática.

O Supremo Tribunal Federal demonstra, com este julgamento, que pode, sim, ser uma Casa do povo, tal qual o parlamento.

${ }^{25}$ Para uma melhor visualização dos enfatizadores e atenuadores identificados, estes serão grifados e aqueles colocados em negrito. Além de ambos estarem em itálico. 
Pergunto ao Tribunal se não seria o caso de deixarmos claro, na própria decisão, que este é o entendimento do Tribunal, quer dizer, não só para o Júri, mas que de fato estamos a emanar uma decisão? ${ }^{26}$

Não há como negar, portanto, a legitimidade democrática da decisão que aqui tomamos hoje. ${ }^{27}$

A questão resumir-se-ia na indagação que poderia ser assim traduzida: que legitimidade teria o Poder Judiciário para afirmar inconstitucional uma lei que o Poder Legislativo votou, o povo quer e a comunidade científica apóia?

No Estado Democrático de Direito, os Poderes constituídos desempenham a competência que Ihes é determinada pela Constituição. Não é exercício de poder, é cumprimento de dever. ${ }^{28}$ Já que decidimos legislar sobre o assunto, não seria melhor exaurir? ${ }^{29}$

Confirma-se hoje que a Constituição Federal é o que o Supremo diz que ela é. ${ }^{30}$

No Brasil, pesquisa efetuada em janeiro último pelo Instituto Ibope revelou o pensamento da população e este deve ser sopesado neste julgamento. ${ }^{31}$

[...] dois motivos me levam a não proferir um voto extremamente simples.

O primeiro deles é pela importância - vamos dizer - política, no alto sentido desta decisão da Corte que deve servir de orientação baseada num caso concreto ${ }^{32}$

Nos votos acima, identificamos o uso de marcadores metadiscursivos de ênfase, que demonstram a certeza dos ministros no que foi dito, colocando a questão como um fato certo. Com isso, procuram finalizar

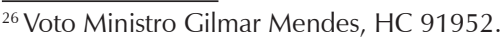

${ }^{27}$ Voto Ministro Gilmar Mendes, ADIN 3510.

${ }^{28}$ Voto Ministra Carmén Lúcia, ADIN 3510.

${ }^{29}$ Voto Ministro Joaquim Barbosa, MI 712.

${ }^{30}$ Voto Ministro Marco Aurélio, MS 26602.

${ }^{31}$ Voto Ministro Marco Aurélio, ADIN 3510.

${ }^{32}$ Voto Ministro Cezar Peluzo, HC 91952.
} 
qualquer controvérsia sobre a questão, ou seja, buscam evitar que sejam levantadas visões contraditórias. Observamos que, nesses votos, os ministros reconhecem e buscam legitimar a atuação legislativa do Supremo, o que demonstra que buscam aumentar as chances de aceitação do discurso.

Por outro lado, nos votos analisados a seguir, não é reconhecida a função legislativa do STF, apesar de também termos identificado os enfatizadores, os quais, conforme já demonstrado, indicam a certeza do posicionamento tomado. Ao contrário, constatamos a preocupação em estabelecer a não atuação do Supremo como legislador positivo.

No presente caso, é bom que se diga e repita, não se está criando norma artificial nem se está ingressando em seara reservada ao poder de legislar. $\boldsymbol{O}$ que se está fazendo é dar uma interpretação coerente com o que se contém na Constituição para preservar-Ihe os princípios estatuídos e assegurar a plenitude do exercício da soberania popular por meio da representação política. ${ }^{33}$

Isto porque não cabe a esta Corte, conforme pacífica jurisprudência, atuar como legislador positivo, função reservada ao Poder Legislativo. ${ }^{34}$ [...] o cuidado com que o Supremo Tribunal Federal sempre enfrentou o risco de extrapolar seus poderes. Acredito que, neste caso, o Tribunal está mantendo esse cuidado, e compartilho das preocupações dos colegas.

Não cabe, pois, ao Poder Judiciário, na matéria em questão, atuar na anômala condição de legislador positivo [...], para, em assim agindo, proceder à imposição de seus próprios critérios de inelegibilidade, afastando, desse modo, os fatores que, no âmbito de nosso sistema constitucional, só podem ser legitimamente definidos pelo Parlamento.

É que, se tal fosse possível, o Poder Judiciário - que não dispõe de função legislativa - passaria a desempenhar atri-

\footnotetext{
$\overline{{ }^{33} \text { Voto Ministro Menezes Direito, MS } 26602 .}$

${ }^{34}$ Voto Ministro Ricardo Lewandowski, RE 579.95.1.
} 
buição que Ihe é institucionalmente estranha (a de legislador positivo), usurpando, desse modo, no contexto de um sistema de poderes essencialmente limitados, competência que não lhe pertence, com evidente transgressão ao princípio constitucional da separação de poderes. ${ }^{35}$

Com isso o Poder Judiciário não estará legislando, absolutamente, não estará decidindo erga omnes; estará se debruçando sobre direitos que Ihe são postulados em concreto e decidindo para o caso concreto.

Nesse caso, ao prestigiar, sobremodo, o Poder Judiciário, a Constituição também dá uma resposta dura - como deve ser - à inércia, à inação do Poder Legislativo. Uma inação grave porque opera de modo a paralisar a Constituição. ${ }^{36}$

Ainda em relação aos votos, identificamos também marcadores de atenuação, os quais indicam o menor comprometimento dos ministros com o que foi dito, colocam a questão como uma opinião, possibilitando, assim, que sejam apresentados outros ponto de vistas sobre a questão.

[...] é possível antever que o Supremo Tribunal Federal acabe por se livrar do vetusto dogma do legislador negativo. ${ }^{37}$

Algumas vezes, o papel do Supremo Tribunal, se não é de protagonista legislativo, é, no entanto, de acicatar aos poderes políticos para o dever de dar efetividade à Constituição. ${ }^{38}$ Comungo das preocupações quanto à não-assunção pelo Tribunal de um protagonismo legislativo. Entretanto, pareceme que a não-atuação no presente momento já se configuraria quase como uma espécie de "omissão judicial".

Com efeito, após a análise dos votos, verificamos que, quanto menos à vontade os ministros se sentem decidindo questões políticas, mais eles se valem de recursos gramaticais na construção dos seus discursos, visando, de alguma forma, em seus votos, justificar suas decisões.

\footnotetext{
${ }^{35}$ Voto Ministro Celso de Mello, ADPF 144

${ }^{36}$ Voto Ministro Carlos Britto, MI 712.

${ }^{37}$ Voto Ministro Gilmar Mendes, ADIN 3510.

${ }^{38}$ Voto Ministro Sepúlveda Pertence, MI 712.
} 
É relevante atentar para o fato de que, analisando a trajetória profissional dos ministros do STF, verificamos que a maior parte teve carreira na magistratura ou foi membro do Ministério Público (MP) ${ }^{39}$. Sendo assim, estão acostumados a trabalhar com a gramática política e, não a produzila. Com isso, pretende-se dizer que os ministros do STF estão acostumados a aplicar a lei aos casos que lhes são apresentados e não a elaborar a lei, função que é tida, pelo senso comum, como típica dos órgãos investidos de Poder Legislativo.

Nesse sentido, é imperioso mencionar que, em estudo realizado por Santos e Da Ros, observou-se, no recrutamento dos ministros do Supremo, uma obediência a um padrão de profissionalização e perícia endógenos, que faz prevalecer as carreiras jurídicas. Segundo estes autores, esse padrão de recrutamento pode ser visto como um "padrão de recrutamento endógeno, como medida da institucionalização da cúpula do Judiciário, pode ser identificado quando isola-se a informação relativa aos membros do STF que percorreram sua carreira profissional exclusivamente em postos do Poder Judiciário" ${ }^{\prime 4}$. Em outro trabalho, Da Ros afirma que são recrutados para o Supremo "juristas profissionais, isto é, indivíduos cujas carreiras priorizaram a ocupação de cargos próprios do universo jurídico" ${ }^{41}$.

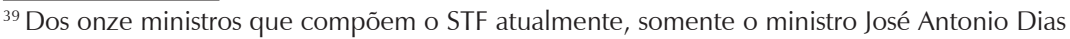
Toffoli não teve carreira na magistratura ou foi membro do MP.

${ }^{40}$ SANTOS, André Marenco dos e DA ROS, Luciano. Caminhos que levam à Corte: carreiras e padrões de recrutamento dos ministros dos órgãos de cúpula do Poder Judiciário brasileiro (1829-2006). Revista de Sociologia e Política [online]. 2008, vol.16, n.30, pp. 131-149.

${ }^{41}$ DA ROS, Luciano. Decretos presidenciais no banco dos réus: análise do controle abstrato de constitucionalidade de medidas provisórias pelo Supremo Tribunal Federal no Brasil (1988-2007). Disponível em: <http://www.lume.ufrgs.br/handle/10183/13819>. Acesso em: 20 jun. 2012.
} 


\section{Conclusões}

Se concluir é fechar, então tudo o que não há, no caso deste artigo, é uma conclusão. Em verdade, a sensação é a de que tudo começa exatamente aqui. Mas, se não podemos concluir, podemos pelo menos tentar mostrar o porquê de não o podermos. Ora, a finalidade deste artigo é contribuir para uma mudança de paradigma na busca da compreensão e consequente produção de conhecimento acerca da realidade política do Brasil de hoje. Segundo nossas crenças, advindas estas da revisão bibliográfica, da leitura de textos não acadêmicos na WEB e mesmo da nossa prática profissional ${ }^{42}$, o paradigma vigente possui pouca força explicativa. Com efeito, as abordagens do papel do Supremo Tribunal Federal na vida política do País, partem da assunção de que ele é um órgão jurisdicional. Esta premissa é montada a partir da simples leitura da Constituição da República. Entretanto, isto é problemático. A constituição é um texto normativo e como tal prescreve, não descreve. Portanto, o fato de estar escrito na Constituição que o STF é um elemento do Poder Judiciário (inclusive como órgão de cúpula) não é suficiente para fazer dele um órgão do Judiciário. Este modo de ver as coisas remonta a um tempo em que a Ciência Política se confundia com os estudos de direito constitucional, e cientistas políticos eram corifeus do direito público.

Nesta ordem de ideias, o muito a que se chegou, em termos doutrinários mais do que teóricos, foi a famosa disputa entre dois grandes constitucionalistas: Hans Kelsen e Carl Schmitt. Se bem que, esta disputa, pelo caráter marcadamente ideológico, não teve ela mesma nada de ingênuo.

${ }^{42} \mathrm{O}$ autor, desde janeiro de 1989, milita em foros judiciais federais e estaduais, o que, para além de mero impressionismo, possibilitou uma visão crítica de como o paradigma (em sentido kuhniano) da separação de poderes opera centralmente na produção do discurso jurídico. 
O cerne da disputa era o seguinte: dada uma Constituição qualquer de um País qualquer, quem deve ser o seu defensor? O pano de fundo dessa discussão era o parlamentarismo, como forma de governo e como forma de Estado (democracia parlamentar). O cenário, a Europa continental do pós-guerra. A Alemanha derrotada de Schmitt e a Áustria de Kelsen. O debate foi importante na consolidação europeia do paradigma constitucional, uma vez que, na prática, Hans Kelsen, enquanto juiz, foi um os mentores da criação e implantação, na Áustria, em 1920, do primeiro tribunal constitucional de que se tem notícia. Um tribunal com esta feição, segundo ele, asseguraria a democracia parlamentar. Este tribunal constitucional sem precedentes inaugurou o que se conhece modernamente como jurisdição constitucional. Com este termo, designa-se o fato de que juízes, dentro de um processo judicialiforme, decidam acerca da constitucionalidade de determinada lei votada pelo parlamento, com poderes de anulá-la se, sob a ótica deste tribunal, a lei contrariar a constituição. Tal procedimento era perfeitamente compatível com o pensamento de Kelsen, segundo o qual, os atos do parlamento não estavam no topo da hierarquia legislativa por ele concebida, dado que, antes de qualquer lei votada pelo parlamento, estava uma lei fundamental (grundnorm) $)^{43}$. Homem de extrema direita, Schmitt, um antiparlamentarista convicto, discordava da possibilidade de que um órgão de extração judiciária pudesse guardar a constituição, papel que, segundo ele, caberia ao Presidente da República. Hoje, tendo em vista o fato de o STF ter sido finalmente

\footnotetext{
${ }^{43}$ Com a licença dos especialistas, acerca do termo grundnorm grassam ensinamentos equivocados. Diz-se, comumente, que a grundnorm é a norma fundamental, isto é, a própria constituição de um Estado. Na verdade, com esta expressão, que não possui referência empírica, Kelsen pretendeu fechar um círculo lógico. Como não concebia bases sociais ao Direito, deu-lhe um fundamento lógico, no sentido de que o direito só poderia ser fundado no próprio direito. A grundnorm, neste sentido, não passa de uma engenhosidade lógica, de um artifício cerebral para, em termos Kelsenianos, purificar o direito de bases sociais e políticas.
} 
percebido como atuando politicamente, o debate gira em torno da legitimidade desta jurisdição constitucional inventada por Kelsen ${ }^{44}$.

Ocorre, entretanto, que o paradigma analítico, ao enxergar separada e hierarquicamente os órgãos centrais do país, não nos parece dar conta do fenômeno político hoje vigente. A expressão jurisdição constitucional é uma vistosa roupagem, com a qual se camufla o fato de o STF ser um elemento original e logo funcional do atual sistema político brasileiro. Se, por jurisdição, deve-se entender uma atuação de corte tipicamente judiciário, com a aplicação de um qualquer direito na solução de uma dada questão, então, não há nada que se pareça com uma jurisdição na atuação do STF. Nem mesmo o adjetivo constitucional fortalece a roupagem como que naturalizando-a. Na origem, a palavra constituição denotava um documento no qual se proclamavam um núcleo de direitos fundamentais e fixava-se a forma de governo e Estado. Esta constituição era a que Kelsen teve em mente. Ora, a constituição brasileira de 1988 é de tal modo extensa, centralizadora, detalhista, que conseguiu prever toda a atividade legiferante, engessando o legislador ordinário. É certo que ela contém uma declaração de direitos e o núcleo da organização do Estado, mas, para, além disto, em seus 234 artigos, ela cuida das questões mais específicas, relembrando a ambição de Napoleão ao promulgar o Código Civil Francês, em 1804. Portanto, ao tratar de tudo, a Constituição tornou-se tão susceptível às violações, que um mero suspiro do legislador pode ser tido como inconstitucional pelos seus guardas. Como se isto não bastasse, a Constituição ainda é recheada de princípios de densidade

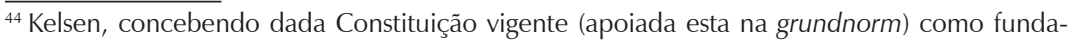
mento de uma ordem jurídica, defendeu a importância da função desempenhada pelos Tribunais Constitucionais nas democracias modernas e tornou-se fonte inspiradora da formação, composição e competências destes. Nas palavras de Kelsen, Jurisdição Constitucional é "a garantia jurisdicional da Constituição" (Kelsen, 2007, p.123).
} 
normativa duvidosa, mas que se prestam como padrão de julgamento de qualquer conduta prática ou normativa.

O STF é um órgão político de caráter nacional. O que se sustenta, contra o senso comum, plasmado este pelo discurso jurídico, e contra, principalmente, a tradição constitucional brasileira, é que o Supremo não é um órgão do Poder Judiciário. O que colocamos em evidência é que a chave de compreensão da função essencialmente política do STF - que, repitamos à exaustão, não integra o Poder Judiciário, mas sim o sistema de governo - está não na observação e no empirismo. Não basta ir aos fatos para compreender o papel do STF. A chave para tal compressão, e esta é uma espécie de sofisticação do jogo, está no próprio discurso constitucional fundante e legitimador das ações dos homens de Estado nas variantes assumidamente democráticas dos governos do século XX do ocidente.

Aceitando, como resultado deste trabalho, a tese de que o STF é um elemento genuíno do sistema político, então, não há como deixar de apontar como elitista o rol constitucional, na medida em que este privilegia, na disputa pela formação da agenda (política) do STF, uns poucos grupos e agências institucionais.

\section{Referências}

ARON, RAYMOND. As etapas do pensamento sociológico. 6aㅡ ed. São Paulo: Martins fontes, 2003.

BECK, Ulrich; GIDDENS, Anthony; LASH, Scott. Modernização Reflexiva: política, tradição e estética na ordem social moderna. São Paulo: Unesp, 1995.

BERTALANFY, Karl Ludwig von. Teoria general de los sistemas: fundamentos, desarrollo, aplicaciones. 7ạ ed. México: Fundo de Cultura Econômica, 1989.

BRASIL. Constituição da república federativa do Brasil. Disponível em: < http:// www.planalto.gov.br/ccivil_03/Constituicao/Constitui\%C3\%A7ao.htm>. Acesso em: 10 out. 2011. 
BRASIL. Supremo Tribunal Federal. Disponível em: <www.stf.hus.br>. Acesso em: 15 out. 2011.

DAHL, Robert A. Quanto è democrática la costituzione americana? Roma-Bari: Laterza, 2003.

DA ROS, Luciano; TAYLOR, Mathew. Os Partidos Dentro e Fora do Poder: A Judicialização como Resultado Contingente da Estratégia Política. DADOS - Revista de Ciências Sociais, Rio de Janeiro, v. 51, n. 4, 2008.

DA ROS, Luciano; Decretos presidenciais no banco dos réus: análise do controle abstrato de constitucionalidade de medidas provisórias pelo Supremo Tribunal Federal no Brasil (1988-2007). Disponível em: < http://www.lume.ufrgs.br/handle/10183/13819>. Acesso em: 20 jun. 2012.

DAY, Robert A.. Cómo escribir y publicar trabajos científicos. Washington: OPS, 2005. (Publicação Científica 598)

DOUGLAS, Mary. Como as instituições pensam. 1a ed. Reimpr. São Paulo: Edusp, 2007.

EASTON, David. Il sistema político. Milano: Edizioni di comunità, 1963.

HUNTIGTON, Samuel P. La terza ondata. I processi di democratizzazione Allá fine Del XX secolo. Bologna: Editora II mulino, 1995.

HYLAND, Ken. Metadiscourse: exploring interaction in writing. London: Continuum, 2005.

KELSEN, Hans. Jurisdição Constitucional. 2ª ed. São Paulo: Martins Fontes, 2007. KUHN, Thomas. A revolução copernicana. São Paulo: Edições 70, 2002.

KUHN, Thomas. A estrutura das revoluções científicas. 7a ed. São Paulo: Perspectiva, 2003.

LUHMAN Niklas. Procedimenti giuridici e legittimazione sociale. Milano: Giuffre editore, 1995.

LUHMANN, Niklas. Sistemi sociali. Fondamenti di una teoria generale. Bologna: II Mulino, 1990.

MACIEL, Débora Alves; KOERNER, Andrei. Sentidos da Judicialização da política: duas análises. Disponível em: < http://www.scielo.br/pdf/ln/n57/a06n57. pdf>. Acesso em: 19 jun. 2012.

MONTESQUIEU. De l'esprit dês lois. Tome premier. Paris: Editions garnier frêres, 1973.

MOSCOVICI, Serge. Representações sociais: investigações em psicologia social. 8a ed. Petrópolis: Vozes, 2011. 
SANTOS, André Marenco dos; DA ROS, Luciano. Caminhos que levam à Corte: carreiras e padrões de recrutamento dos ministros dos órgãos de cúpula do Poder Judiciário brasileiro (1829-2006). Revista de Sociologia e Política, Curitiba, v.16, n.30, p. 131-149, 2008.

SARTORI, Giovanni. A política: lógica e método nas ciências sociais, 2 ed. a Brasília: UnB, 1997.

SARTORI, Giovanni. Democracia Cosa è. Milano: Rizzoli, 2007.

SCHMITT, Carl. Legalidade e legitimidade. Belo Horizonte: Del Rey, 2007.

SOLA, Giorgio. Incontro con la scienza politica. Bologna: II mulino, 2006.

SOUZA, Braz Florentino Henriques de. Do poder moderador. Brasília: UnB, 1978.

VIANNA, Luís Werneck. A democracia e dos três poderes no Brasil. Belo Horizonte: UFMG, 2002.

Recebido em: 14/03/2012

Aceite final: 09/07/2012 